American Journal of Food Technology 6 (11): 974-984, 2011

ISSN 1557-4571 / DOI: 10.3923/ajft.2011.974.984

(C) 2011 Academic Journals Inc.

\title{
Assessment of a Maturity Index in Jabuticaba Fruit by the Evaluation of Phenolic Compounds, Essential Oil Components, Sugar Content and Total Acidity
}

\author{
Gilmara A.C. Fortes, Sara S. Naves, Fabiana F.F. Godoi, Alessandra R. Duarte, \\ Pedro H. Ferri and Suzana C. Santos \\ Institute of Chemistry, Federal University of Goiás, 74001-970 Goiânia, G•, Brazil
}

Corresponding Author: Suzana da Costa Santos, Laboratory of Molecular Bioactivity, Institute of Chemistry, Federal University of Goiás, Goiânia, G•, 74001-970, Brazil Tel: +556235211008

\begin{abstract}
Jabuticaba is a Brazilian tree with edible grape like fruits which are consumed fresh or used to prepare jams, liqueurs and wines. The aim of this study was to identify the optimal harvest period for winemaking by monitoring chemical parameters during jabuticaba's development. Jabuticaba fruit was analysed at four developmental stages for total acidity, reducing sugars, anthocyanins, tannins, total phenols and essential oil composition. Total acidity significantly decreased (15.46-4.56 g citric acid $100 \mathrm{~g}^{-1}$ ), whereas reducing sugars increased about threefold in pulps up until the full ripe stage (32.52-88.92 $\mathrm{g}$ glucose equivalent $\left.100 \mathrm{~g}^{-1}\right)$. Anthocyanin levels underwent a sharp increase in the skins reaching $22.0 \mathrm{mg}$ cyanidin 3 -glucoside equivalent $\mathrm{g}^{-1}$ at complete maturation. Tannins and total phenols showed no significant differences in their levels between ripe and full ripe stages. The essential oil contains $88.1 \%$ of sesquiterpene compounds, being $\gamma$-eudesmol (33.9\%) and $\alpha$-eudesmol (15.5\%) the major constituents. Some minor terpenoids changed significantly in their contents during jabuticaba's maturation. The monoterpenes $\alpha$-pinene, $\beta$-pinene, (E)- $\beta$-ocimene, linalool and $\alpha$-terpineol increased while the sesquiterpenes amorpha-4,7(11)-diene, $\delta$-amorphene, $\delta$-cadinene and $\alpha$-cadinene decreased from green to ripe stages. However the major terpenoids showed no significant changes. Results demonstrated that the use of sugar/acid ratio and anthocyanin concentration seemed to be the most effective parameters to reveal the optimal harvest period for winemaking.
\end{abstract}

Key words: Myrciaria cauliflora, Myrtaceae, fruit ripening, terpenoids, tannins, anthocyanins

\section{INTRODUCTION}

Jabuticaba (Myrciaria cauliflora Berg.) is a short multi-stemmed Brazilian tree; its flowers and fruits grow directly on the main truck and stems (Reynertson et al., 2006). Jabuticaba berries have a slightly acid to sweet taste as well as thick and tough purple to blackish skin (Lima et al., 2011). In the popular medicine, the decoction of the skins is used as a treatment for hemoptysis, cough, bronchitis, asthma, diarrhea and dysentery, as well as a rinse for chronic throat inflammation (Reynertson et al., 2006; Stefanello et al., 2011). Two depsides were isolated from deseeded fruits and exhibited antiradical activity in DPPH assay, colon cancer cell cytotoxicity and inhibition of interleukin IL-8 production, suggesting anti-inflammatory activity (Reynertson et al., 2006). The fruit ethanol extract also showed inhibitory effect against $K$. pneumoniae (Haminiuk et al., 2011), 
while leaf extracts were effective against several oral bacteria and Candida species (Macedo-Costa et al., 2009; Souza-Moreira et al., 2010).

Several reports have described their antioxidant activity which is mainly attributed to the high anthocyanin and flavonoid content in their skins (Einbond et al., 2004; Reynertson et al., 2008; De Assis et al., 2009; Romero et al., 2010; Santos et al., 2010; Rufino et al., 2010; Leite et al., 2011; Haminiuk et al., 2011). Recently, optimization of anthocyanin extraction from jabuticaba skins was performed using high pressure $\mathrm{CO}_{2}$, ultrasound treatment and combination of different solvents and pH (Santos and Meireles, 2011; Santos et al., 2010; Montes et al., 2005).

Besides its biological activities, jabuticaba berries have been used to produce jams, liqueurs, distillates and wines, as an alternative to prevent post-harvesting losses (Reynertson et al., 2006; Agostini et al., 2009). In the last decade jabuticaba wine production has grown and the success among consumers has increased. The target now is to improve its quality (Da Silva et al., 2008; Duarte et al., 2010b), through the optimization of fermentation conditions (Duarte et al., 2011) or by managing the attributes of jabuticaba berries (Danner et al., 2011). The wine quality is affected directly by fruit composition which is influenced by many extrinsic factors, such as climatic conditions, soil and harvesting date (Gómez-Míguez, et al., 2007; Pérez-Magariño and GonzálezSan José, 2006). It is well known that phenolic and terpenoid compounds which are responsible for some of wine's organoleptic properties, such as colour, flavour, body and structure of red wines (Gómez-Míguez et al., 2007) alter during fruit development and ripening (Fadda and Mulas, 2010; Coelho et al., 2006). However, there is no information on the concentration of tannins, total phenols and terpenoid compounds during jabuticaba growth and maturation. In addition, the composition of jabuticaba's essential oil has not been previously reported.

Therefore, the main objective of this paper was to assess the optimal harvest period for winemaking, through the analysis of the evolution of phenolic and essential oil compounds, reducing sugar and total acidity during jabuticaba's development and ripening.

\section{MATERIALS AND METHODS}

Plants, materials and chemicals: Cultivated $M$. cauliflora fruits var. Pingo de mel were collected in September and October 2008 at Jabuticabal Winery ( $16^{\circ} 55^{\prime} 25.9^{\prime \prime}$, W 49 $21^{\prime} 41.0^{\prime \prime}$ ), located in the outskirts of Hidrolândia, Goiás State, Brazil. About $2 \mathrm{~kg}$ of each fruit sample were obtained from 10 to 20 year-old trees. Fruit harvesting was performed at four developmental stages: 16-, 23-, 30- and 37-days after anthesis (DAA). After harvesting, part of the berries was washed with running water and separated manually into its components (skin, pulp and seeds) and $100 \mathrm{~g}$ samples of berries and each separated part were blended with $50 \mathrm{~mL}$ distilled water and freeze-dried. Dried samples were stored at $-18^{\circ} \mathrm{C}$ until analysis. Tannic acid and iron (III) chloride were purchased from Merck (Darmstadt, Germany). Dinitros alicylic acid, Folin-Ciocalteu's phenol reagent and Bovine Serum Albumin were purchased from Sigma-Aldrich (St. Louis, MO, USA). All other chemicals used were of analytical grade. After each harvest, three groups of 50 fresh berries were averaged for fresh weight measurement.

Extracts for reducing sugar and total acidity assay preparation: Freeze-dried berries or pulp $(0.2 \mathrm{~g})$ were extracted at $50^{\circ} \mathrm{C}$ with $10 \mathrm{~mL}$ of distilled water in an ultrasonic bath for $30 \mathrm{~min}$. The extract was separated from the solid residue by centrifuging at 4,000 rpm for $15 \mathrm{~min}$ and transferred to a $25 \mathrm{~mL}$ volumetric flask. The same procedure was repeated twice with 10 and $5 \mathrm{~mL}$ of water for $15 \mathrm{~min}$ each. The extracts were combined in a final $25 \mathrm{~mL}$ volume and were prepared in triplicate. 
Extracts for phenol assay preparation: One gram of freeze-dried berries or separated parts (skin, pulp and seeds) was homogenized with $10 \mathrm{~mL}$ of $\mathrm{MeOH}$-formic acid (9:1) in a test tube and sonicated for $30 \mathrm{~min}$. The extract was centrifuged, filtered and the marc extracted three more times for $15 \mathrm{~min}$. Extracts were combined and concentrated under reduced pressure at $35^{\circ} \mathrm{C}$ and brought up to $25 \mathrm{~mL}$ in a volumetric flask. Extracts were prepared in triplicate.

Extraction of fruit essential oil: Frozen berries (ca. $500 \mathrm{~g}$ ) were crushed in small pieces and submitted to hydrodistillation ( $2 \mathrm{~h}$ ) by means of a modified Clevenger-type apparatus. At the end of each distillation essential oils were collected, dried with anhydrous $\mathrm{Na}_{2} \mathrm{SO}_{4}$, transferred to glass flasks and kept at a temperature of $-18^{\circ} \mathrm{C}$ until analysis. Oil yields (\%) were based on the fresh weight of fruit samples.

Determination of reducing sugar: Reducing sugar content was determined by the 3,5dinitrosalicylic acid (DNSA) method (Miller, 1959). Results were expressed as glucose equivalent $100 \mathrm{~g}^{-1}$ dried fruit. Measurements were performed in triplicate.

Determination of total acidity: Total acidity was measured by titrating an aliquot (5.0 mL) of the extract with $0.01 \mathrm{~mol} \mathrm{~L}^{-1}$ of $\mathrm{NaOH}$ to $\mathrm{pH} 8.2$. The results were expressed as g citric acid $100 \mathrm{~g}^{-1}$ dried fruit. Measurements were performed in triplicate.

Determination of phenolic compounds: Total phenols were quantified by the Folin-Ciocalteu method described by Escarpa and Gonzalez (2001). Results were expressed as mg tannic acid equivalent $\mathrm{g}^{-1}$ dried fruit or its parts. Measurements were performed in triplicate.

Tannins were measured by protein precipitation assay with the use of Bovine Serum Albumin (Hagerman-Butler method described by Waterman and Mole (1994). Results were expressed as mg tannic acid equivalent $\mathrm{g}^{-1}$ dried fruit or its parts. Measurements were performed intriplicate.

Anthocyanin content was determined by the $\mathrm{pH}$-differential method (Wrolstad et al., 2005; Reynertson et al., 2008). Pigment concentration is expressed as cyanidin 3-glucoside equivalents per g of dry weight (DW). Measurements were performed in triplicate.

Fruit essential oil analyses: Oil sample analyses were performed on a GC-MS Shimadzu QP5050A instrument under the following conditions: A CBP-5 (Shimadzu) fused silica capillary column (30 $\mathrm{m} \times 0.25 \mathrm{~mm}$ i.d., $0.25 \mu \mathrm{m}$ film thickness) connected to a quadrupole detector operating in the EI mode at $70 \mathrm{eV}$ with a scan mass range of $40-400 \mathrm{~m} / \mathrm{z}$ at a sampling rate of $1.0 \mathrm{scan} / \mathrm{s}$; carrier gas: He $\left(1 \mathrm{~mL} \mathrm{~min}{ }^{-1}\right)$; injector and interface temperatures of 220 and $240^{\circ} \mathrm{C}$, respectively, with a split ratio of $1: 20$. The injection volume was $0.4 \mu \mathrm{L}$ (ca. $20 \%$ in hexane) and the oven temperature was raised from 60 to $246^{\circ} \mathrm{C}$ with an increase of $3^{\circ} \mathrm{C} / \mathrm{min}$, then $10 / \mathrm{min}$ to $270^{\circ} \mathrm{C}$ and the final temperature was held for $5 \mathrm{~min}$. Individual components were identified by comparing their linear retention indices, which were determined by a co-injection with a $\mathrm{C}_{8}-\mathrm{C}_{32} \mathrm{n}$-alkanes series (Sigma, USA) and mass spectra with those of the literature (Adams, 2007) and a computerized MS-database using NIST libraries (NIST, 1998).

Statistical analysis: Experimental data were assessed by one-way ANOVA using SAS GLM analyses (Statistical Analysis System, SAS Institute Inc., Cary, NC, 1996). All data was checked for homoscedasticity with the use of Hartley's test (Kanji, 2006). Whenever a difference was 
Am. J. Food Technol., 6 (11): 974-984, 2011

established, a post-hoc Tukey test was performed. Results are shown as mean values and are joined by the standard deviation of independent measurements in some cases. The p-values below 0.05 were regarded as significant.

\section{RESULTS AND DISCUSSION}

The complete development of jabuticaba fruits usually takes 45-60 days after anthesis (Magallhães et al., 1996); however, fruits may complete maturation in 35 days during a hot dry season with proper irrigation and soil conditions (Andersen and Andersen, 1989). This is the case at Jabuticabal Winery's orchard where berries grow rapidly, therefore, four development stages were chosen: green (16 DAA), turning to purple (23 DAA), ripe (30 DAA) and full ripe (37 DAA).

Fruit fresh weight, reducing sugars and titratable acidity: Results for fruit weight, reducing sugars content and total acidity of jabuticaba fruits are presented in Table 1. The fresh fruit weight increased significantly until 30 DAA (2.51-7.67 g), from this date occurred a substantial reduction to $5.02 \mathrm{~g}$. The reduction in the fruit's fresh weight could be due to water loss. A similar growth pattern was observed in berries such as myrtles, plums and grapes (Fadda and Mulas, 2010) and this is the opposite for pomegranate fruit which has a continuous weight increase during maturation (Shwartz et al., 2009).

Reducing sugars content in pulp had significant growth in all stages, while for the whole fruit considerable differences were observed mainly from green to full ripe stages

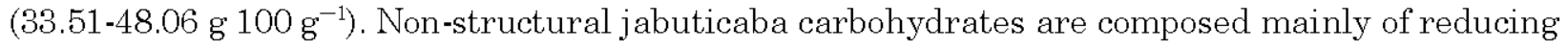
sugars, which make up about $90 \%$ of total soluble sugars and accumulate mostly in the pulps, even though pulps account to only 36 to $49 \%$ of the fruit (Barros et al., 1996; Lima et al., 2011). Comparable to results at full ripe stage (Table 1) when the reducing sugars content in the pulps

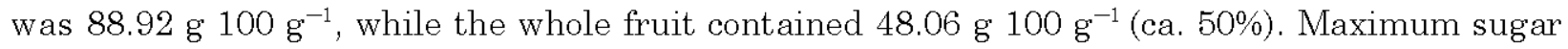
content in the pulp at 37 DAA was very similar to $80 \mathrm{~g} 100 \mathrm{~g}^{-1}$ DW obtained for $M$. jaboticaba at 60 days (Barros et al., 1996).

Throughout jabuticaba's development, total acidity presented a constant and significant decrease in all stages. The acidity values dropped from 15.46 to $4.56 \mathrm{~g}$ citric acid $100 \mathrm{~g}^{-1}$ which is a reduction of about $70 \%$ (Table 1). Similar results were observed in two jabuticaba varieties (Sabará and Açú Paulista), in which succinic and citric acids reduced 71.3\% on average in the pulp during maturation (Jham et al., 2007); the same occurred with myrtle berries, which showed a $70 \%$ decrease in titrable acidity (Fadda and Mulas, 2010). The most abundant organic acids detected and quantified in jabuticaba fruits were succinic and citric acids (Jham et al., 2007). Malic, oxalic and acetic acids were also detected although in lower amounts (Lima et al., 2011).

Changes in sugar and total acidity levels mean that sugar/acid ratio increased during fruit development from 2.17 (16 DAA) to 10.5 (37 DAA). This ratio can be used as a maturity index, which measures fruit quality for industrial purposes; nevertheless, there are limitations as regards variability between fruits, cultivars and year of observation (Kingston, 1992).

Total phenols, tannins and anthocyanins: Table 2 displays the results from anthocyanins, tannins and total phenols assays in parts and the whole jabuticaba fruit at four developmental stages.

A comparison of anthocyanin amounts during maturation (Table 2) showed a significant increase in the skins and also in the whole fruit levels, while seeds and pulps did not change. 
Am. J. Food Technol., 6 (11): 974-984, 2011

Table 1: Average concentrations $\mathrm{s}^{\mathrm{a}}$ of fresh weight (g), reducing sugars and total acidity ( $100 \mathrm{~g}^{-1}$, dry weight basis) in jabuticaba fruit/parts during development

\begin{tabular}{|c|c|c|c|c|}
\hline \multirow[b]{2}{*}{$\mathrm{DAA}^{\mathrm{b}}$} & \multirow[b]{2}{*}{ Fresh weight fruit } & \multicolumn{2}{|c|}{ Reducing sugars } & \multirow[b]{2}{*}{ Total acidity fruit } \\
\hline & & Pulp & Fruit & \\
\hline 16 & $2.51 \pm 0.14 \mathrm{C}$ & $32.52 \pm 0.55 \mathrm{aD}$ & $33.51 \pm 0.19 \mathrm{aC}$ & $15.46 \pm 0.22 \mathrm{~A}$ \\
\hline 23 & $4.77 \pm 0.14 \mathrm{~B}$ & $56.57 \pm 2.48 \mathrm{aC}$ & $42.24 \pm 0.83 \mathrm{bB}$ & $13.36 \pm 0.11 \mathrm{~B}$ \\
\hline 30 & $7.67 \pm 0.09 \mathrm{~A}$ & $66.21 \pm 0.08 \mathrm{aB}$ & $43.55 \pm 0.80 \mathrm{bB}$ & $7.14 \pm 0.11 \mathrm{C}$ \\
\hline 37 & $5.02 \pm 0.35 \mathrm{~B}$ & $88.92 \pm 0.13 \mathrm{aA}$ & $48.06 \pm 0.07 \mathrm{bA}$ & $4.56 \pm 0.03 \mathrm{D}$ \\
\hline
\end{tabular}

${ }^{a}$ Values are Means \pm RSD $(n=3)$. ${ }^{b}$ Days after anthesis. Means followed by the same capital letter in the columns and by the same small letter in the rows (for reducing sugars) did not share significant differences at $5 \%$ probability by Tukey's test

Table 2: Average concentrations $\mathrm{s}^{\mathrm{a}}$ of anthocyanins, tannins and total phenols ( $\mathrm{mg} \mathrm{g}^{-1}$, dry weight basis) in jabuticaba fruit/parts during development

\begin{tabular}{|c|c|c|c|c|c|c|c|c|c|c|c|c|}
\hline \multirow[b]{2}{*}{ DAA } & \multicolumn{4}{|c|}{ Anthocyanins } & \multicolumn{4}{|l|}{ Tannins } & \multicolumn{4}{|c|}{ Total phenols } \\
\hline & Seed & Pulp & Skin & Fruit & Seed & Pulp & Skin & Fruit & Seed & Pulp & Skin & Fruit \\
\hline 16 & $0.84 \mathrm{aA}$ & $0.42 \mathrm{aA}$ & $0.43 \mathrm{aD}$ & $0.56 \mathrm{aD}$ & $7.75 \mathrm{aA}$ & $4.02 \mathrm{bA}$ & $7.27 \mathrm{aA}$ & $8.16 \mathrm{aA}$ & $18.0 \mathrm{cA}$ & $13.7 \mathrm{dA}$ & $34.2 \mathrm{aA}$ & $24.2 \mathrm{bA}$ \\
\hline 23 & $0.70 \mathrm{cA}$ & $0.58 \mathrm{cA}$ & $2.16 \mathrm{aC}$ & $1.34 \mathrm{bC}$ & $6.61 \mathrm{aB}$ & $3.90 \mathrm{bB}$ & $6.78 \mathrm{aB}$ & $7.20 \mathrm{aB}$ & $16.3 \mathrm{cC}$ & $12.3 \mathrm{~dB}$ & $33.2 \mathrm{aA}$ & $18.5 \mathrm{bB}$ \\
\hline 30 & $0.57 \mathrm{cA}$ & $0.45 \mathrm{cA}$ & $12.5 \mathrm{aB}$ & $5.94 \mathrm{bB}$ & $6.97 \mathrm{aB}$ & $3.15 \mathrm{bB}$ & $7.21 \mathrm{aB}$ & $7.06 \mathrm{aB}$ & $16.6 \mathrm{bAB}$ & $6.8 \mathrm{dC}$ & $32.9 \mathrm{aA}$ & $14.9 \mathrm{cC}$ \\
\hline 37 & $0.31 \mathrm{cA}$ & $0.63 \mathrm{cA}$ & $22.0 \mathrm{aA}$ & $12.0 \mathrm{bA}$ & 7.33aAB & $3.12 \mathrm{bAB}$ & 7.44aAB & $6.88 \mathrm{aAB}$ & $17.0 \mathrm{bAB}$ & $6.3 \mathrm{dC}$ & $33.4 \mathrm{aA}$ & $12.7 \mathrm{cC}$ \\
\hline
\end{tabular}

aValues are means $(n=3)$. Means followed by the same capital letter in the columns and by the same small letter in the rows did not share significant differences at $5 \%$ probability by Tukey's test

Anthocyanins are phenolic compounds responsible for fruit colour (Abyari et al., 2006). They accumulate in jabuticaba's skin $\left(22.0 \mathrm{mg} \mathrm{g}^{-1}\right)$, whereas the fruit's pulp is whitish $\left(0.63 \mathrm{mg} \mathrm{g}^{-1}\right)$. Their steep rise of about fiftyfold in the skins $\left(0.43-22.0 \mathrm{mg} \mathrm{g}^{-1}\right)$ between 16 and 37 days is due to the production of cyanidin-3-glucose (Reynertson et al., 2008) and petunidin-3-glucose (Montes et al., 2005). A previous study on $M$. jaboticaba showed a similar increase of about 48-fold in anthocyanidin contents from green to ripe fruit (Magalhães et al., 1996). Other fruits also reveal the same drastic increase in pigment levels during ripening, such as myrtle, American cramberry and pomegranate arils (Fadda and Mulas, 2010; Vvedenskaya and Vorsa, 2004; Kulkarni and Aradhya, 2005).

Total anthocyanin values for ripe jabuticabas (5.94 and $12.0 \mathrm{mg} \mathrm{g}^{-1}$ ) were higher than those for $M$. cauliflora fruits grown in the USA $\left(2.78 \mathrm{mg}^{-1}\right.$ ) (Reynertson et al., 2008). Climate parameters such as temperature could be responsible for this difference. Anthocyanin accumulation is influenced by air temperature, particularly by temperature variation between day and night (Treutter, 2010). As has been reported for strawberries, hot days and cool nights increase the production of pelargonidin and cyanidin glycosides (Wang and Zheng, 2001).

Anthocyanin levels in ripe jabuticabas are of crucial importance for wine production, since higher quantities of anthocyanins extracted from fruits will enhance the colour and antioxidant properties of the wine (Tuberoso et al., 2007). Anthocyanin concentration may be yet another parameter for maturity index, as its level grows until full ripeness.

Total tannin (condensed and hydrolysable) accumulated mainly in seeds and skins, where they were about twofold higher than in pulps at all stages (Table 2). During ripening, tannin contents had a significant variation in all parts and the whole fruit only from green to turning purple stages (seed 7.75-6.61, pulp 4.02-3.90, skin 7.27-6.78 and fruit 8.16-7.20 $\mathrm{mg} \mathrm{g}^{-1}$ ); in the following stages 
its levels remain constant. This tendency is opposite from skin and seed grape tannins that generally decline during all stages of maturation (Kennedy et al., 2000; Obreque-Slier et al., 2010). A continuous reduction in the tannin contents is also usual for other fruits, such as myrtle and persimmon (Fadda and Mulas, 2010; Del Bubba et al., 2009).

For the production of red wine, in which seeds and skins remain in contact with must, it is necessary to become aware of the adequate amounts of tannins in seeds and skins to avoid deficiency or excess of these compounds (Busse-Valverde et al., 2010; Mercurio et al., 2010).

Total phenol (phenolic acids, depsides, flavonoids, anthocyanins and tannins) levels of seeds, pulps and the whole fruit changed significantly from 16 to 23 DAA (seed 18.0-16.3, pulp 13.7-12.3 and fruit 24.2-18.5 $\mathrm{mg} \mathrm{g}^{-1}$ ) and from 23 to 30 DAA (seed 16.3-16.6, pulp 12.3-6.8 and fruit $18.5-14.9 \mathrm{mg} \mathrm{g}^{-1}$ ). The phenols concentrations were significant different comparing seed, pulp, skin and the whole jabuticaba fruit in all stages (see rows in Table 2); and they were about twofold and fivefold higher in the skins $\left(32.9 \mathrm{mg} \mathrm{g}^{-1}\right)$ when compared to seeds $\left(16.6 \mathrm{mg} \mathrm{g}^{-1}\right)$ and pulp $\left(6.8 \mathrm{mg} \mathrm{g}^{-1}\right)$ in a full ripe fruit, respectively. The opposite trend was observed for Carménère and Cabernet Sauvignon grapes which total phenolics contents were about fifteenfold higher in seeds compared to skins (Obreque-Slier et al., 2010).

During fruit maturation, total phenol amounts in skins did not alter significantly (Table 2), whereas pulps reduced $7.4 \mathrm{mg} \mathrm{g}^{-1}$ from green to ripe stages and the whole fruit had $11.5 \mathrm{mg} \mathrm{g}^{-1}$ less phenols in the full ripe stage. This tendency to total phenol reduction during maturation has also been observed in other fruits, such as myrtle, American cranberry and apple (Fadda and Mulas, 2010; Vvedenskaya and Vorsa, 2004; Renard et al., 2007).

Essential oils: Essential oils were analysed in three stages: green (16 DAA), turning purple (23 DAA) and ripe (30 DAA). A total of 27 compounds were identified, accounting for 96.0-97.3\% of volatile constituents, with average yields of 0.0009, 0.0020 and $0.0028 \mathrm{wt} \%$ (Table 3). Essential oils from the three maturation stages were composed mainly of cyclic sesquiterpenes (average of 88.1\%); the same tendency was observed in the leaf oil from $M$. cauliflora (Duarte et al., 2010a) and in other species from Myrcia, Eugenia and Psidium genera of the Myrtaceae family (Stefanello et al., 2011). Major jabuticaba components were $\gamma$-eudesmol (33.9\%) and $\alpha$-eudesmol (15.5\%) which is an unusual essential oil composition for Myrtaceae, as (E)-caryophyllene is generally the predominant sesquiterpene (Stefanello et al., 2011). The leaf oil is also different from the fruit, as germacrene D (24.1\%) and $\beta$-eudesmol (16.5\%) are the major compounds (Duarte et al., 2010a). Among the monoterpenes, limonene, (Z)-, (E)- $\beta$-ocimene and $\alpha$-terpineol were the main compounds in all three stages; usually they provide citric, green and flowery aromas (Bicas et al., 2011).

During jabuticaba's maturation stage, the monoterpene and sesquiterpene groups (hydrocarbons and oxygenated) did not altered significantly. Only minor compounds had a significant variation during fruit ripening, such as the most odoriferous monoterpene alcohols $\alpha$-terpineol and linalool that varied from 0.37 to $1.79 \%$ and from 0.01 to $1.01 \%$, respectively (Table 3). These monoterpenols are important aromatic components of muscat grape varieties (Oliveira et al., 2004). The lack of variation in terpenoids groups differs from results reported for mango var. "Kensington Pride" and Vitis vinifera L. cv. Baga (Lalel et al., 2003; Coelho et al., 2006), in which sesquiterpenes increased sharply in ripe fruits. Sesquiterpenoids were detected in several $V$. vinifera varieties; they are related to spicy and wood aromas, which may contribute positively to the quality of wine aromas (Coelho et al., 2006; Jiang et al., 2007). 
Am. J. Food Technol., 6 (11): 974-984, 2011

Table 3: Average percentages ${ }^{a}$ of essential oil constituents of jabuticaba fruits during development

\begin{tabular}{|c|c|c|c|c|}
\hline \multirow[b]{2}{*}{ Constituent } & \multirow[b]{2}{*}{ RI } & \multicolumn{3}{|c|}{ Days after anthesis (DAA) } \\
\hline & & 16 & 23 & 30 \\
\hline$\alpha$-pinene & 933 & $0.01 b$ & $0.40 \mathrm{a}$ & $0.54 a$ \\
\hline$\beta$-pinene & 976 & $0.01 b$ & $0.41 \mathrm{a}$ & $0.74 a$ \\
\hline$\beta$-myrcene & 990 & $0.25 \mathrm{a}$ & $0.01 b$ & $0.01 \mathrm{~b}$ \\
\hline Limonene & 1028 & $1.98 \mathrm{a}$ & $2.03 \mathrm{a}$ & $2.63 \mathrm{a}$ \\
\hline (Z)- $\beta$-ocimene & 1035 & $0.83 \mathrm{a}$ & $0.88 \mathrm{a}$ & $1.11 \mathrm{a}$ \\
\hline (E)- $\beta$-ocimene & 1046 & $1.07 \mathrm{a}$ & $1.45 \mathrm{ab}$ & $2.29 \mathrm{~b}$ \\
\hline Linalool & 1100 & $0.01 b$ & $0.01 \mathrm{~b}$ & $1.01 \mathrm{a}$ \\
\hline$\alpha$-terpineol & 1191 & $0.37 \mathrm{~b}$ & $1.19 \mathrm{a}$ & $1.79 \mathrm{a}$ \\
\hline 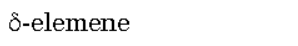 & 1338 & $0.01 \mathrm{a}$ & $0.71 \mathrm{a}$ & $0.38 \mathrm{a}$ \\
\hline$\alpha$-copaene & 1377 & $0.80 \mathrm{a}$ & $1.25 \mathrm{a}$ & $1.03 \mathrm{a}$ \\
\hline (E)-caryophyllene & 1421 & $4.37 \mathrm{a}$ & $6.09 \mathrm{a}$ & $5.73 a$ \\
\hline$\alpha$-humuleno & 1455 & $0.39 \mathrm{a}$ & $1.04 \mathrm{a}$ & $1.07 \mathrm{a}$ \\
\hline Amorpha-4,7(11)-diene & 1477 & $0.57 \mathrm{a}$ & $0.66 \mathrm{a}$ & $0.01 \mathrm{~b}$ \\
\hline Germacrene D & 1483 & $6.93 a$ & $6.06 \mathrm{a}$ & $6.02 \mathrm{a}$ \\
\hline 8-selinene & 1492 & $1.84 \mathrm{a}$ & $0.83 a$ & $0.85 \mathrm{a}$ \\
\hline Bicyclogermacrene & 1498 & $3.68 \mathrm{a}$ & $3.62 \mathrm{a}$ & $3.98 \mathrm{a}$ \\
\hline$\delta$-amorphene & 1503 & $0.67 \mathrm{a}$ & $0.48 \mathrm{a}$ & $0.01 \mathrm{~b}$ \\
\hline 8-cadinene & 1525 & $3.98 \mathrm{a}$ & $3.39 \mathrm{ab}$ & $2.34 \mathrm{~b}$ \\
\hline$\alpha$-cadinene & 1541 & $0.37 \mathrm{a}$ & $0.41 \mathrm{a}$ & $0.01 \mathrm{~b}$ \\
\hline Elemol & 1552 & $0.01 \mathrm{~b}$ & $0.01 \mathrm{~b}$ & $1.23 \mathrm{a}$ \\
\hline Globulol & 1586 & $1.22 \mathrm{a}$ & $2.13 \mathrm{a}$ & $1.61 \mathrm{a}$ \\
\hline 5-epi-7-epi- $\alpha$-eudesmol & 1604 & $1.16 \mathrm{a}$ & $1.19 \mathrm{a}$ & $0.44 \mathrm{a}$ \\
\hline 10-epi- $\gamma$-eudesmol & 1622 & $3.14 \mathrm{a}$ & $2.68 \mathrm{a}$ & $1.59 \mathrm{a}$ \\
\hline$\gamma$-eudesmol & 1637 & $34.4 \mathrm{a}$ & $32.5 \mathrm{a}$ & $34.7 \mathrm{a}$ \\
\hline Cubenol & 1645 & $3.46 \mathrm{a}$ & $2.63 \mathrm{a}$ & $1.13 \mathrm{a}$ \\
\hline$\beta$-eudesmol & 1654 & $7.80 \mathrm{a}$ & $5.22 \mathrm{a}$ & $10.1 \mathrm{a}$ \\
\hline$\alpha$-eudesmol & 1658 & $16.8 \mathrm{a}$ & $14.6 \mathrm{a}$ & $15.1 \mathrm{a}$ \\
\hline \multicolumn{2}{|c|}{ Monoterpene hydrocarbons } & $4.13 \mathrm{a}$ & $5.16 \mathrm{a}$ & $7.28 \mathrm{a}$ \\
\hline \multicolumn{2}{|l|}{ Oxygenated monoterpenes } & $0.38 \mathrm{a}$ & $1.20 \mathrm{a}$ & $2.80 \mathrm{a}$ \\
\hline \multicolumn{2}{|c|}{ Sesquiterpene hydrocarbons } & $23.6 \mathrm{a}$ & $24.5 \mathrm{a}$ & $21.4 \mathrm{a}$ \\
\hline \multicolumn{2}{|c|}{ Oxygenated sesquiterpenes } & $67.9 \mathrm{a}$ & $61.0 \mathrm{a}$ & $65.8 \mathrm{a}$ \\
\hline \multicolumn{2}{|l|}{ Total identified } & $96.0 \mathrm{a}$ & $91.9 \mathrm{a}$ & $97.3 \mathrm{a}$ \\
\hline \multicolumn{2}{|l|}{ Yield $(\%, w / w)$} & $0.0009 \mathrm{a}$ & $0.0020 \mathrm{a}$ & 0.002 \\
\hline
\end{tabular}

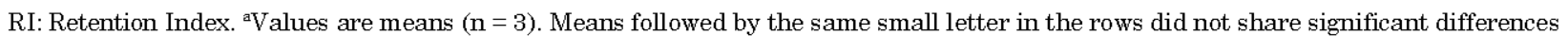
at $5 \%$ probability by Tukey's test

\section{CONCLUSIONS}

Jabuticaba fruits showed some chemical changes during development and ripening. The use of sugar/acid ratio and anthocyanin concentration seemed to be the most effective parameters to reveal the optimal harvest period for winemaking. Tannins and total phenols were not useful as parameters for a maturity index, since their levels failed to show significant differences between ripe and full ripe stages. Anthocyanin levels and sugar/acid ratio reached their maximum in the full ripe stage which suggests that harvesting for wine production should occur after 35 DAA. In addition, jabuticaba volatile compounds, mainly sesquiterpene $\gamma-, \alpha$ - and $\beta$-eudesmols, may add an exotic feature to the wine aroma. 
Am. J. Food Technol., 6 (11): 974-984, 2011

\section{ACKNOWLEDGMENTS}

The authors are indebted to CNPq, PADCT III and FUNAPE/UFG for their financial support, as well as to CAPES for granting fellowships to G.A.C.F. and A.R.D. We also thank Dr. Paulo Antônio Silva from Jabuticabal Winery for providing valuable plant information and for helping with fruit collection.

\section{REFERENCES}

Abyari, M., R. Heidari and R. Jamei, 2006. The effects of heating, UV irradiation and $\mathrm{pH}$ on stability of siahe sardasht grape Anthocyanin-copigment complex. J. Boil. Sci., 6: 638-645.

Adams, R.P., 2007. Identification of Essential Oil Components by Gas Chromatography/Mass Spectrometry. 4th Edn., Illinois, Allured, ISBN-10: 1932633219.

Agostini, J.S., A.C.S. Candido, T.K.C. Teodosio, J.N. Rodrigues, G.J. Garcete and S.P.Q. Scalon, 2009. Modified atmosphere and storage conditions in jaboticabas cv paulista physicochemistry characteristics. Cienc. Rural, 39: 2601-2608.

Andersen, O. and V.U. Andersen, 1989. As Frutas Silvestres Brasileiras (The Brazilian wild fruits). Sao Paulo, Globo, ISBN: 85-250-0517-7 pp: 206.

Barros, R.S., F.L. Finger and M.M. Magalhães, 1996. Changes in non-strucutal carbohydrates in developing fruit of Myrciaria jaboticaba. Sci. Hort., 66: 209-215.

Bicas, J.L., G. Molina, A.P. Dionisio, F.F.C. Barros, R. Wagner, M.R. Marostica Jr. and G.M. Pastore, 2011. Volatile constituents of exotic fruits from Brazil. Food Res. Int., 44: $1843-1855$.

Busse-Valverde, N., E. Gomez-Plaza, J.M. Lopez-Roca, R. Gil-munoz, J.I. Fernandez-Fernandez and A.B. Bautista-Ortin, 2010. Effect of different enological practices on skin and seed proanthocyanidins in three varietal wines. J. Agric. Food Chem., 58: 11333-11339.

Coelho, E., S.M. Rocha, I. Delgadillo and M.A. Coimbra, 2006. Headspace-SPME applied to varietal volatile components evolution during Vitis vinifera L. cv. Baga ripening. Anal. Chim. Acta, 563: 204-214.

Da Silva, P.H.A., F.C. de Faria, B. Tonon, S.J.D. Mota and V.T. Pinto, 2008. Evaluation of the chemical composition of wine produced from jabuticaba (Myrciaria jabuticaba). Quim. Nova, 31: 595-600.

Danner, M.A., I. Citadin, S.A.Z. Sasso, S. Scariot and G. Benin, 2011. Genetic dissimilarity among jabuticaba trees native to southwestern Paraná, Brazil. Rev. Bras. Frutic., 33: 517-525.

De Assis, S.A., J.C.R. Vellosa, I.L. Brunetti, N.M. Khalil and K.M.D.S.C. Leite et al., 2009. Antioxidant activity, ascorbic acid and total phenol of exotic fruits occurring in Brazil. Int. J. Food Sci. Nutr., 60: 439-448.

Del Bubba, M., E. Giordani, L. Pippucci, A. Cincinelli, L. Checchini and P. Galvan, 2009. Changes in tannins, ascorbic acid and sugar content in astringent persimmons during on-tree growth and ripening and in response to different postharvest treatments. J. Food Compost. Anal., 22: 668-677.

Duarte, A.R., S.C. Santos, J.C. Seraphin and P.H. Ferri, 2010a. Environmental influence on phenols and essential oils of Myrciaria cauliflora leaves. J. Braz. Chem. Soc., 21: 1672-1680.

Duarte, W.F., D.R. Dias, J.M. Oliveira, J.A. Teixeira, J.B. de Almeida e Silva and R.F. Schwan, 2010b. Characterization of different fruit wines made from cacao, cupuassu, gabiroba, jaboticaba and umbu. LWT- Food Sci. Technol., 43: 1564-1572. 
Duarte, W.F., J.C. Amorim, L.D.A. Lago, D.R. Dias and R.F. Schwan, 2011. Optimization of fermentation conditions for production of the jabuticaba (Myrciaria cauliflora) spirit using the response surface methodology. J. Food Sci., 76: C782-C790.

Einbond, L.S., K.A. Reynertson, X.D. Luo, M.J. Basile and E.J. Kennelly, 2004. Anthocyanin antioxidants from edible fruits. Food Chem., 84: 23-28.

Escarpa, A. and M.C. Gonzalez, 2001. Approach to the content of total extractable phenolic compounds from different food samples by comparison of chromatographic and spectrophotometric methods. Anal. Chim. Acta, 427: 119-127.

Fadda, A. and M. Mulas, 2010. Chemical changes during myrtle (Myrtus communis L.) fruit development and ripening. Sci Hort., 125: 477-485.

Gómez-Míguez, M.J., M.Gómez-Míguez, I.M. Vicario and F.J. Heredia, 2007. Assessment of colour and aroma in white wines vinifications: Effects of grape maturity and soil type. J. Food Eng., 79: $758-764$.

Haminiuk, C.W.I., M.S.V. Plata-Oviedo, A.R. Guedes, A.P. Stafussa, E. Bona and S.T. Carpes, 2011. Chemical, antioxidant and antibacterial study of Brazilian fruits. Int. J. Food Sci. Technol., 46: 1529-1537.

Jham, G.N., S.A. Fernandes, C.F. Garcia and D. Palmquist, 2007. Comparison of GC and HPLC for quantification of organic acids in two jaboticaba (Myrciaria) fruit varieties. Quim. Nova, 30: 1529-1534.

Jiang, W., W. Fan, Y. Xu, G. Zhao, J. Li and Y. Yu, 2007. Analysis of free terpenoids in Vitis vinifera using solvent assisted flavour evaporation and gas chromatography-tandem mass spectrometry. Chin. J. Chromatogr., 25: 881-886.

Kanji, G.K., 2006. 100 Statistical Tests. 3rd Edn., Sage Publication Ltd., London, ISBN13: 978-8178297316, page: 242.

Kennedy, J.A., M.A. Matthews and A.L. Waterhouse, 2000. Changes in grape seed polyphenols during fruit ripening. Phytochemistry, 55: 77-85.

Kingston, C.M., 1992. Maturity indices for apple and pear. Hort. Rev., 13: 407-432.

Kulkarni, A.P. and S.M. Aradhya, 2005. Chemical changes and antioxidant activity in pomegranate arils during fruit development. Food Chem., 93: 319-324.

Lalel, H.J.D., Z. Singh and S.C. Tan, 2003. Aroma volatiles production during fruit ripening of Kensington Pride mango. Postharvest Biol. Technol., 27: 323-336.

Leite, A.V., L.G. Malta, M.F. Riccio, M.N. Eberlin, G.M. Pastore and M.R. Jr. Marostica, 2011. Antioxidant potential of rat plasma by administration of freeze-dried Jaboticaba peel (Myrciaria jaboticaba Vell Berg). J. Agric. Food Chem., 59: 2277-2283.

Lima, A.D.J.B., A.D. Correa, A.M. Dantas-Barros, D.L. Nelson and A.C.L. Amorim, 2011. Sugars, organic acids, minerals and lipids in jabuticaba. Rev. Bras. Frutic., 33: 540-550.

Macedo-Costa, M.R., D.N. Diniz, C.M. Carvalho, M.D.S.V. Pereira, J.V. Pereira and J.S. Higino, 2009. Effectiveness of the Myrciaria cauliflora (Mart.) O. Berg. extract on oral bacteria. Braz. J. Pharmacogn., 19: 565-571.

Magalhães, M.M., R.S. Barros and N.F. Lopes, 1996. Growth relations and pigment changes in developing fruit of Myrciaria jaboticaba. J. Hort. Sci. Biothechnol., 71: 925-930.

Mercurio, M.D., R.G. Dambergs, D. Cozzolino, M.J. Herderich and P.A. Smith, 2010. Relationship between red wine grade and phenolics. 1. Tannin and total phenolics concentration. J. Agric. Food Chem., 58: 12313-12319. 
Miller, G.L., 1959. Use of dinitrosalicylic acid reagent for determination of reducing sugar. Anal. Chem., 31: 426-428.

Montes, C., I.M. Vicario, M. Raymundo, R. Fett and F.J. Heredia, 2005. Application of tristimulus colorimetry to optimize the extraction of anthocyanins from Jaboticaba (Myricia Jaboticaba Berg.). Food Res. Int., 38: 983-988.

NIST, 1998. PC version of the NIST/EPA/NIH mass spectral database. US. Department of Commerce, Gaithersburg.

Obreque-Slier, E., A. Pena-Neira, R. Lopez-Solis, F. Zamora-Marin, J.M. Ricardo-da Silva and O. Laureano, 2010. Comparative study of the phenolic composition of seeds and skins from carménère and cabernet sauvignon grape varieties (Vitis vinifera L.) during ripening. J. Agric. Food Chem., 58: 3591-3599.

Oliveira, J.M., I.M. Araujo, O.M. Pereira, J.S. Maia, A.J. Amaral and M.O. Maia, 2004. Characterization and differentiation of five "Vinhos verdes" grape varieties on the basis of monoterpenic compounds. Anal. Chim. Acta, 513: 269-275.

Pérez-Magariño, S. and M.L. Gonzàlez-San José, 2006. Polyphenols and colour variability of red wines made from grapes harvested at different ripeness grade. Food Chem., 96: 197-208.

Renard, C.M.G.C., N. Dupont and P. Guillermin, 2007. Concentrations and characteristics of procyanidins and other phenolics in apples during fruit growth. Phytochemistry, 68: 1128-1138.

Reynertson, K.A., A.M. Wallace, S. Adachi, R.R. Gil and H. Yang et al., 2006. Bioactive depsides and anthocyanins from jaboticaba (Myrciaria cauliflora). J. Nat. Prod., 69: 1228-1230.

Reynertson, K.A., H. Yang, B. Jiang, M.J. Basile and E.J. Kennelly, 2008. Quantitative analysis of antiradical phenolic constituents from fourteen edible Myrtaceae fruits. Food Chem., 109: 883-890.

Romero, M., B. Rojano, J. Mella-Raipan, C.D. Pessoa-Mahana, E. Lissi and C. Lopez-Alarcon, 2010. Antioxidant capacity of pure compounds and complex mixtures evaluated by the ORAC-pyrogallol red ass ay in the presence of triton X-100 micelles. Molecules, 15: 6152-6167.

Rufino, M.D.S.M., R.E. Alves, E.S. de Brito, J. Perez-Jimenez, F. Saura-Calixto and J. Mancini-Filho, 2010. Bioactive compounds and antioxidant capacities of 18 non-traditional tropical fruits from Brazil. Food Chem., 121: 996-1002.

Santos, D.T. and M.A.A. Meireles, 2011. Optimization of bioactive compounds extraction from jabuticaba (Myrciaria cauliflora) skins assisted by high pressure $\mathrm{CO}_{2}$. Innov. Food Sci. Emerg. Technol., 12: 398-406.

Santos, D.T., P.C. Veggi and M.A.A. Meireles, 2010. Extraction of antioxidant compounds from Jabuticaba (Myrciaria cauliflora) skins: Yield, composition and economical evaluation. J. Food Eng., 101: 23-31.

Shwartz, E., I. Glazer, I. Bar-Yaakov, I. Matityahu, I. Bar-Ilan, D. Holland and R. Amir, 2009. Changes in chemical constituents during the maturation and ripening of two commercially important pomegranate accessions. Food Chem., 115: 965-973.

Souza-Moreira, T.M., R.R.D. Moreira, L.V.S. Sacramento and R.C.L.R. Pietro, 2010. Histochemical, phytochemical and biological screening of Plinia cauliflora (DC.) Kausel, Myrtaceae, leaves. Braz. J. Pharmacogn., 20: 48-53.

Stefanello, M.E.A., A.C.R.F. Pascoal and M.J. Salvador, 2011. Essential oils from neotropical Myrtaceae: Chemical diversity and biological properties. Chem. Biodivers, 8: 73-94.

Treutter, D., 2010. Managing phenol contents in crop plants by phytochemical farming and breeding-Visions and constraints. Int. J. Mol. Sci., 11: 807-857. 
Tuberoso, C.I.G., M. Melis, A. Angioni, M. Pala and P. Cabras, 2007. Myrtle hydroalcoholic extracts obtained from different selections of Myrtus communis L. Food Chem., 101: 806-811.

Vvedenskaya, I.O. and N. Vorsa, 2004. Flavonoid composition over fruit development and maturation in America cranberry, Vaccinium macrocarpon Ait. Plant Sci., 167: 1043-1054.

Wang, S.Y. and W. Zheng, 2001. Effect of plant growth temperature on antioxidant capacity in strawberry. J. Agric. Food Chem., 49: 4977-4982.

Waterman, P.G. and S. Mole, 1994. Analysis of Phenolic Plant Metabolites. 1st Edn., Blackwell Scientific Publication, Oxford.

Wrolstad, R.E., R.W. Durst and J. Lee, 2005. Tracking color and pigment changes in anthocyanin products. Trends Food Sci. Technol., 16: 423-428. 